[Chem. Pharm. Bull.

35( 8 )3482-3486(1987)

\title{
A New Amino Acid, (2S,3R)-(-)-3-Hydroxybaikiain from Russula subnigricans HONGO
}

\author{
Genjiro Kusano, ${ }^{a}$ Hiroko Ogawa, ${ }^{a}$ Akira Takahashi ${ }^{a}$ \\ Shigeo NOZOE ${ }^{*, a}$ and KAZUMASA YOKOYAMA ${ }^{b}$ \\ Pharmaceutical Institute, Tohoku University, ${ }^{a}$ Aobayama, Sendai 980, Japan and \\ Faculty of Education, Shiga University, ${ }^{b}$ Hiratsu, Otsu 520, Japan
}

(Received February 6, 1987)

\begin{abstract}
A new amino acid (I) was isolated from a toxic mushroom, Russula subnigricans HoNGo, and characterized as $(2 S, 3 R)-(-)$-3-hydroxybaikiain $[(2 S, 3 R)-(-)-1,2,3,6$-tetrahydro-3-hydroxypyridine-2-carboxylic acid]. (S)-(-)-Baikiain (II), $(S)$-(-)-pipecolic acid (III), ergosterol (IV), ergosteryl peroxide (V) and cerevisterol (VI) were also isolated and identified.
\end{abstract}

Keywords-Russula subnigricans; Russula nigricans; Russula adusta; Lactarius piperatus; Basidiomycetes; amino acid; $(2 S, 3 R)-(-)$-3-hydroxybaikiain; $(S)-(-)$-baikiain; $(S)$-( - )-pipecolic acid; ergosterol; ergosteryl peroxide; cerevisterol

A new amino acid (I), $\mathrm{C}_{6} \mathrm{H}_{9} \mathrm{O}_{3} \mathrm{~N},(2 S, 3 R)-(-)$-3-hydroxybaikiain $[(2 S, 3 R)-(-)-1,2,3,6-$ tetrahydro-3-hydroxypyridine-2-carboxylic acid], was isolated from a toxic mushroom, Russula subnigricans HONGO (Russulaceae) (Japanese name: nisekurohatsu), along with $(S)$ (-)-baikiain (II), (S)-(-)-pipecolic acid (III), ergosterol (IV), ergosteryl peroxide (V) and cerevisterol (VI). The structure of I was elucidated on the basis of the spectroscopic data and the results of chemical transformation. Analysis of amino acids of this mushroom on an analyzer showed the presence of aspartic acid, glutamic acid, threonine, glycine, alanine, proline, tyrosine, phenylalanine, methionine, $\gamma$-aminobutyric acid, canavanine, cystine, valine, isoleucine, leucine, serine, lysine, histidine and arginine besides the above amino acids. Here we wish to report the isolation procedure and the structural elucidation of I and also the identification of other constituents.

The toxic mushroom, Russula subnigricans HONGO, is closely similar to an edible mushroom, R. nigricans (MERAT) FR. (Japanese name; kurohatsu). The latter mushroom shows blackening after reddening, while the former shows prolonged reddening. Intoxication of eleven persons, including three fatal cases, has been described. ${ }^{1)}$

Dried carpophores were extracted with methanol, and the extract was partitioned between ethyl acetate and water. The ethyl acetate layer was chromatographed on silica gel and the ergosterol, its peroxide and cerevisterol were isolated and identified. The water layer was applied to an Amberlite XAD-2 column and the passed fraction was chromatographed on Amberlite IR-120. The adsorbed partition was eluted with $2 \mathrm{~N}$ ammonia solution. The residue after evaporation of the solvent was subjected to chromatography on cellulose. The new amino acid (I) $\mathrm{C}_{6} \mathrm{H}_{9} \mathrm{O}_{3} \mathrm{~N}$, mp $300-302^{\circ} \mathrm{C}$, was obtained as colorless needles after recrystallization of the fractions eluted with $n$-butanol saturated with water from a mixture of methanol and water.

The signals of the carbon-13 nuclear magnetic resonance $\left({ }^{13} \mathrm{C}-\mathrm{NMR}\right)$ spectrum of I were characterized by consideration of the chemical shifts and the splitting in the off-resonance spectrum. The signal (1C) at $171.49 \mathrm{ppm}$ was attributed to a carbon of a carboxyl group. Signals (2C) at 126.81 and $123.70 \mathrm{ppm}$ were assigned to two carbons of a 1,2-disubstituted 
double bond. The signal (2C) at $60.82 \mathrm{ppm}$ was assigned to two carbons having a hydroxy and an amino group. The signal (1C) at $42.39 \mathrm{ppm}$ was assigned to a carbon of a methylene group attached to an amino group. The signals of the proton nuclear magnetic resonance $\left({ }^{1} \mathrm{H}\right.$ NMR) spectrum of I were characterized with the aid of the results of irradiation experiments as summarized in Fig. 1.

Because the $[\alpha]_{\mathrm{D}}$ value of $I$ in a neutral water solution was $-332.7^{\circ}$ and that in $1 \mathrm{~N} \mathrm{HCl}$ solution was $-324.0^{\circ}$, this amino acid should be $\mathrm{L}-\mathrm{form} .^{2)}$ The coupling constant $(J=3 \mathrm{~Hz})$ between the carbinyl hydrogen and the $\alpha$-hydrogen of the amino carboxylic acid suggests $c i s-$ configuration. Therefore, the new amino acid (I) was concluded to be $(2 S, 3 R)-(-)-3-$ hydroxybaikiain $[(2 S, 3 R)-(-)-1,2,3,6$-tetrahydro-3-hydroxypyridine-2-carboxylic acid]. This

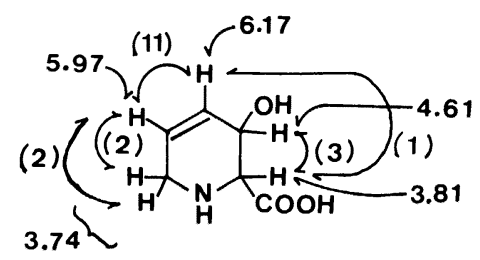

Fig. 1. ${ }^{1} \mathrm{H}-\mathrm{NMR}$ Chemical Shifts and Coupling Constants (in Parenthesis) of I

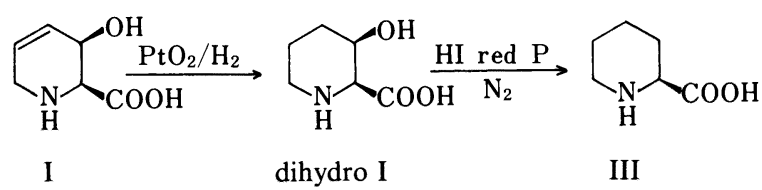

Fig. 2
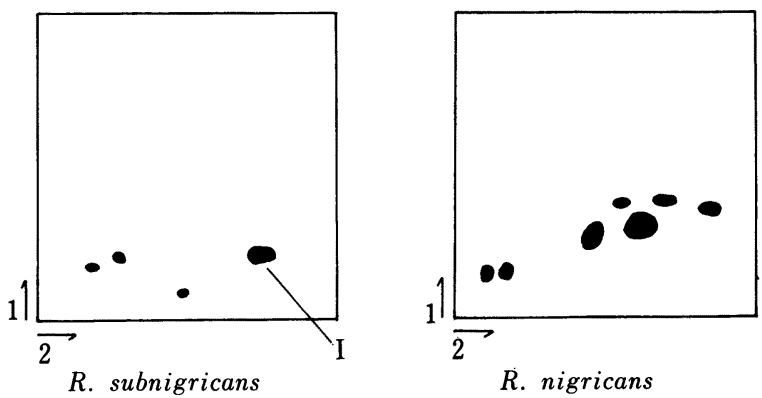

R. nigricans
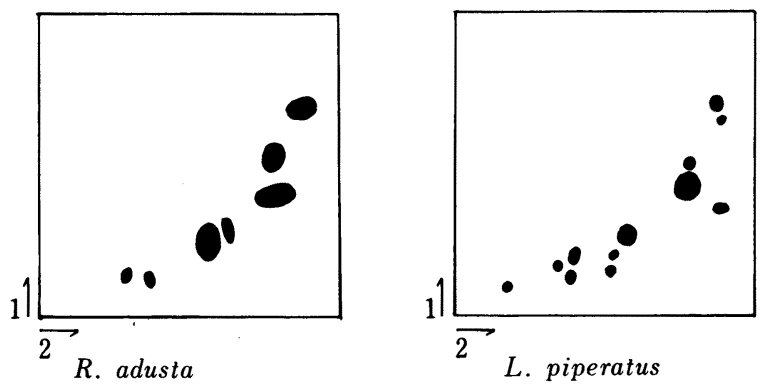

Fig. 3. Two-Dimensional Thin Layer Chromatograms of Amino Acids from 4 Mushrooms

1. $\mathrm{BuOH}: \mathrm{AcOH}: \mathrm{H}_{2} \mathrm{O}=4: 1: 1$. 2. Phenol saturated with $\mathrm{H}_{2} \mathrm{O}$. 3. Kieselgel $60 \mathrm{~F}_{254} 4$. Ninhydrin, $120^{\circ} \mathrm{C}$. 
conclusion was supported by the derivation into $(S)$-(-)-pipecolic acid (III) via the dihydro derivative, which was obtained through catalytic hydrogenation of the new amino acid (I), by treatment with red phosphorus and hydroiodic acid as shown in Fig. 2.

$(S)$-( - -)-Baikiain (II) and (S)-(-)-pipecolic acid (III) were isolated from the mother solution of recrystallization of I by preparative high performance liquid chromatography (HPLC) and identified as described in the experimental section. The former amino acid, which is a deoxy derivative of $\mathrm{I}$, was isolated from Baikiaea plurijuna (Leguminosae) and its structure was elucidated in $\left.1950 . .^{3}\right)$ This amino acid was also isolated from Caesalpinia tinctoria and some allied species (Leguminosae), ${ }^{4)}$ and it was detected in leaves of Derris elliptica ${ }^{5}$ and some marine algae. ${ }^{6)}$ Some biological activities of $\mathrm{L}-(-)$-baikiain, especially an inhibitory activity towards glutamate as a neurotransmitter, were reported. ${ }^{7)}$ Because the new amino acid (I) showed no toxicity in mice given $1 \mathrm{~g} / \mathrm{kg}$ perorally, work to identify the toxic principles of this mushroom is continuing.

On comparing the two-dimensional paper chromatograms of amino acids of $R$. subnigricans, $R$. nigricans, $R$. adusta (FR.) FR. (Japanese name: kogeirohatsutake) and Lactarius piperatus (FR.) S. F. GRAY, which all belong to the Russula family (the former three species are extremely similar to each other, and are difficult to differentiate), the new amino acid (I) was detected only in the case of $R$. subnigricans (Fig. 3). Therefore, the amino acid may be specific to this mushroom and may be useful for the identification of the mushroom, though more mushrooms of Russula genus and family are being investigated to confirm this.

\section{Experimental $^{8)}$}

Isolation of the New Amino Acid (I) - Dried fruiting bodies (250 g) of Russula subnigricans Hongo were extracted with methanol three times at room temperature. After evaporation of the solvent in vacuo, the residual extract was partitioned between ethyl acetate and water. The ethyl acetate solution was separated and the aqueous solution was subjected to Amberlite IRC-50 column chromatography after removal of dissolved ethyl acetate by evaporation under reduced pressure. The passed fraction was applied to an Amberlite IR-120 column. The adsorbed fraction was eluted with $2 \mathrm{~N}$ ammonia solution. The eluted fraction was concentrated under reduced pressure to remove ammonia and the residual solution was applied to an Amberlite IR-45 column after dilution with distilled water. The passed fraction was concentrated in vacuo and the residue was chromatographed on cellulose.

A new amino acid (I) was obtained as colorless needles $(3.5 \mathrm{~g})$ after recrystallization from aqueous methanol. The followig properties were observed: $\mathrm{mp} 300-302^{\circ} \mathrm{C}$. Anal. Calcd for $\mathrm{C}_{6} \mathrm{H}_{9} \mathrm{NO}_{3}: \mathrm{C}, 50.34 ; \mathrm{H}, 6.34 ; \mathrm{N}, 9.79$. Found: $\mathrm{C}$, 50.07; H, 6.30; N, 9.96. $[\alpha]_{\mathrm{D}}^{20}-332.7^{\circ}\left(\mathrm{H}_{2} \mathrm{O}, c=0.3\right),-324.0^{\circ}(1 \mathrm{~N} \mathrm{HCl}, c=0.3)$. $R f$ on Avicel thin layer chromatography (TLC): $0.15\left[\mathrm{BuOH}-\mathrm{AcOH}-\mathrm{H}_{2} \mathrm{O}(4: 1: 1)\right]$, as a yellow spot after usual treatment with ninhydrin. $t_{R}$ on HPLC: $4.3 \mathrm{~min}$ ( $\# 2618,8 \mathrm{~mm}$ i.d. $\times 50 \mathrm{~cm}$, elution with pH $3.05 \mathrm{NH}_{3}-\mathrm{HCOOH}$ buffer, flow rate $3.0 \mathrm{ml} / \mathrm{min}$, detected on radioisotope). IR (KBr) cm $\mathrm{cm}^{-1}: 3300(\mathrm{OH}), 3000,2400(\mathrm{NH}), 1660,1390$ (carboxylate). MS (FD): $m / z 144$ $\left(\mathrm{M}^{+}+\mathrm{H}\right), 99.70 .{ }^{13} \mathrm{C}-\mathrm{NMR}\left(\mathrm{D}_{2} \mathrm{O}\right) \mathrm{ppm}: 171.49(1 \mathrm{C}, \mathrm{s}, \underline{\mathrm{COOH}}), 126.81(1 \mathrm{C}, \mathrm{d}, \underline{\mathrm{CH}}=\mathrm{CH}), 123.70(1 \mathrm{C}, \mathrm{d}, \mathrm{CH}=\mathrm{CH})$, $60.82(2 \mathrm{C}, \mathrm{d}, \underline{\mathrm{C}} \mathrm{H}-\mathrm{O}$ and $\underline{\mathrm{C}} \mathrm{H}-\mathrm{N}), 42.39\left(1 \mathrm{C}, \mathrm{t}, \underline{\mathrm{CH}}_{2}-\mathrm{N}\right) .{ }^{1} \mathrm{H}-\mathrm{NMR}\left(\mathrm{D}_{2} \mathrm{O}\right) \mathrm{ppm}: 3.74\left(2 \mathrm{H}\right.$, unresolved signal, $\left.\mathrm{C}_{6}-2 \mathrm{H}\right)$, $3.81\left(1 \mathrm{H}\right.$, splitted d, $\left.J=3 \mathrm{~Hz}, \mathrm{C}_{2}-\mathrm{H}\right), 4.61\left(1 \mathrm{H}\right.$, unresolved, $\left.\mathrm{C}_{3}-\mathrm{H}\right), 5.97$ and $6.17\left(2 \mathrm{H}, \mathrm{m}, \mathrm{C}_{5}-\mathrm{H}\right.$ and $\left.\mathrm{C}_{4}-\mathrm{H}\right) .{ }^{1} \mathrm{H}-\mathrm{NMDR}$ $\left(\mathrm{D}_{2} \mathrm{O}\right)$ : Irradiation at $4.61 \mathrm{ppm}$ collapsed the multiplet at 6.17 and $5.97 \mathrm{ppm}$ into a doublet $(1 \mathrm{H}, J=11 \mathrm{~Hz})$ and a sextet $\left(1 \mathrm{H}, J_{1}=11, J_{2}=J_{3}=2 \mathrm{~Hz}\right)$, and transformed the unresolved signal at $3.74 \mathrm{ppm}$ to a doublet $(2 \mathrm{H}, J=2 \mathrm{~Hz})$, and the split signal at $3.81 \mathrm{ppm}$ to a doublet $(1 \mathrm{H}, J=1 \mathrm{~Hz})$. Irradiation at $6.0 \mathrm{ppm}$ collapsed the signal at $4.61 \mathrm{ppm}$ into a doublet $(1 \mathrm{H}, J=3 \mathrm{~Hz})$, the split doublet at $3.81 \mathrm{ppm}$ to a doublet $(1 \mathrm{H}, J=3 \mathrm{~Hz})$, and the unresolved signal at $3.74 \mathrm{ppm}$ into a singlet $(2 \mathrm{H})$.

Isolation of $(S)-(-)$-Baikiain (II) - The residue after recrystallization of I was subjected to HPLC for isolation. The fraction eluted at $t_{R} 27 \mathrm{~min}$ with $\mathrm{pH} 3.05 \mathrm{NH}_{3}-\mathrm{HCOOH}$ buffer from a $\# 2618$ column $(8 \mathrm{~mm}$ i.d. $\times 50 \mathrm{~cm})$ at $3.0 \mathrm{ml} / \mathrm{min}$ flow rate was taken. The collected fraction was recrystallized from aqueous methanol and baikiain (27 mg) was obtained as colorless prisms: $\mathrm{mp} 265-270^{\circ} \mathrm{C} .[\alpha]_{\mathrm{D}}^{20}-288^{\circ}\left(\mathrm{H}_{2} \mathrm{O}, c=0.1\right) . R f 0.20$ on Avicel TLC as a yellow spot after usual treatment with ninhydrin reagent $\left[\mathrm{BuOH}-\mathrm{AcOH}-\mathrm{H}_{2} \mathrm{O}(4: 1: 1)\right] . \mathrm{IR}(\mathrm{KBr}) \mathrm{cm}^{-1}: 3000,2400(\mathrm{NH}), 1660$ $\left(\mathrm{COO}^{-}\right) .{ }^{13} \mathrm{C}-\mathrm{NMR}\left(\mathrm{D}_{2} \mathrm{O}\right) \mathrm{ppm}: 173.95(1 \mathrm{C}, \mathrm{s}, \mathrm{COOH}), 125.11(1 \mathrm{C}, \mathrm{d}, \mathrm{CH}=\mathrm{CH}), 119.47(1 \mathrm{C}, \mathrm{d}, \mathrm{CH}=\mathrm{CH}), 55.07$ (1C, d, HNCHCOOH), $41.74\left(1 \mathrm{C}, \mathrm{t}, \mathrm{CH}_{2} \mathrm{NH}\right), 25.42\left(1 \mathrm{C}, \mathrm{t}, \underline{\mathrm{CH}}_{2}\right) .{ }^{1} \mathrm{H}-\mathrm{NMR}\left(\mathrm{D}_{2} \mathrm{O}\right) \mathrm{ppm}: 2.44\left(1 \mathrm{H}\right.$, octet, $J_{1}=18$, $\left.J_{2}=12, J_{3}=3 \mathrm{~Hz}, \mathrm{C}_{3}-\mathrm{H}\right), 2.70\left(1 \mathrm{H}\right.$, unresolved d, $\left.J=18 \mathrm{~Hz}, \mathrm{C}_{3}-\mathrm{H}\right), 3.76\left(2 \mathrm{H}, \mathrm{m}, \mathrm{C}_{6}-2 \mathrm{H}\right), 3.80\left(1 \mathrm{H}, \mathrm{m}, \mathrm{C}_{2}-\mathrm{H}\right), 5.9(2 \mathrm{H}$, $\mathrm{m}, \mathrm{C}_{4}-\mathrm{H}$ and $\left.\mathrm{C}_{5}-\mathrm{H}\right) .{ }^{1} \mathrm{H}-\mathrm{NMR}\left(\mathrm{D}_{2} \mathrm{O}\right)$ : Irradiation at $5.9 \mathrm{ppm}$ collapsed the multiplet at $3.80 \mathrm{ppm}$ into a singlet. 
Irradiation at $2.44 \mathrm{ppm}$ collapsed the multiplet at $5.9 \mathrm{ppm}$ into a doublet (lower signal, $1 \mathrm{H}, J=11 \mathrm{~Hz}$ ) and a sextet (higher signal, $1 \mathrm{H}, J_{1}=10 \mathrm{~Hz}, J_{2}=J_{3}=3 \mathrm{~Hz}$ ). Irradiation at $3.8 \mathrm{ppm}$ collapsed the multiplet at $5.9 \mathrm{ppm}$ into an octet (lower signal, $1 \mathrm{H}, J_{1}=11, J_{2}=4, J_{3}=2 \mathrm{~Hz}$ ) and a sextet (higher signal, $1 \mathrm{H}, J_{1}=11, J_{2}=J_{3}=1 \mathrm{~Hz}$ ), the octet at $2.44 \mathrm{ppm}$ into a doublet $(1 \mathrm{H}, J=18 \mathrm{~Hz})$ and the unresolved doublet into a double doublet $\left(1 \mathrm{H}, J_{1}=18, J_{2}=4 \mathrm{~Hz}\right)$. The melting point, IR and NMR spectra were identical with those of reported L- $(-)$-baikiain.

Identification of $(S)$-(-)-Pipecolic Acid (III)- The residue after recrystallization of I was subjected to preparative HPLC (the same column, eluted with $\mathrm{pH} 3.4 \mathrm{NH}_{3}-\mathrm{HCOOH}$ buffer, at $0.5 \mathrm{ml} / \mathrm{min}$ flow rate). A peak at $t_{R}$ $15 \mathrm{~min}$ was found to be identical with that of an authentic specimen of L-pipecolic acid. TLC: $R f 0.35$ [BuOH$\left.\mathrm{AcOH}-\mathrm{H}_{2} \mathrm{O}(4: 1: 1)\right]$. The collected fraction was recrystallized from $\mathrm{MeOH}$ to provide colorless needles $(9 \mathrm{mg})$. $[\alpha]_{D}^{20}-32.5^{\circ}\left(\mathrm{H}_{2} \mathrm{O}, c=0.1\right)$. The IR and NMR spectra were identical with those of an authentic specimen of Lpipecolic acid.

Hydrogenation of the New Amino Acid (I)_- I ( $50 \mathrm{mg})$ was dissolved in a mixture of water $(5 \mathrm{ml})$ and methanol $(5 \mathrm{ml})$, and platinum dioxide $(20 \mathrm{mg})$ was added. Hydrogen gas was introduced with stirring at room temperature for $4 \mathrm{~h}$. The catalyst was filtered off and the filtrate was concentrated under reduced pressure to provide the dihydro derivative $(45 \mathrm{mg})$ after recrystallization from $\mathrm{MeOH}$. The product, $\mathrm{mp}>300^{\circ} \mathrm{C},[\alpha]_{\mathrm{D}}^{20}-93.3^{\circ}\left(c=0.3, \mathrm{H}_{2} \mathrm{O}\right)$ was identified as $(2 S, 3 R)-(-)$-3-hydroxypipecolic acid on the basis of the following data: MS (FD): $m / z 146\left(\mathrm{M}^{+}+\mathrm{H}\right)$, $128\left(\mathrm{M}^{+}+\mathrm{H}-\mathrm{H}_{2} \mathrm{O}\right), 100\left(\mathrm{M}^{+}-\mathrm{CO}_{2}-2 \mathrm{H}\right) .{ }^{1} \mathrm{H}-\mathrm{NMR}\left(\mathrm{D}_{2} \mathrm{O}\right) \mathrm{ppm}: 1.95\left(4 \mathrm{H}, \mathrm{m}, \mathrm{C}_{4}-2 \mathrm{H}\right.$ and $\left.\mathrm{C}_{5}-2 \mathrm{H}\right), 3.02(1 \mathrm{H}, \mathrm{t}, J=$ $\left.10 \mathrm{~Hz}, \mathrm{C}_{6}-\mathrm{H}\right), 3.48(1 \mathrm{H}, \mathrm{d}, J=10 \mathrm{~Hz}), 3.72\left(1 \mathrm{H}, \mathrm{s}, \mathrm{C}_{2}-\mathrm{H}\right), 4.54\left(1 \mathrm{H}\right.$, unresolved s, $\left.\mathrm{C}_{3}-\mathrm{H}\right) .{ }^{1} \mathrm{H}-\mathrm{NMDR}\left(\mathrm{D}_{2} \mathrm{O}\right) \mathrm{ppm}$ : Irradiation at $4.54 \mathrm{ppm}$ increased the height of the singlet at $3.72 \mathrm{ppm}$, irradiation at 3.02 and 3.48 ppm changed the splitting pattern of the multiplet at $1.95 \mathrm{ppm}$, and irradiation at $1.95 \mathrm{ppm}$ collapsed the doublet at $3.48 \mathrm{ppm}$ into a sharpened doublet and the triplet at $3.02 \mathrm{ppm}$ into a doublet.

Reduction of (2S,3R)-(-)-3-Hydroxypipecolic Acid-The dihydro derivative $(30 \mathrm{mg})$ was heated with $\mathrm{HI}$ $0.5 \mathrm{ml}$ and red phosphorus $10 \mathrm{mg}$ in a shielded tube at $140^{\circ} \mathrm{C}$ for $5 \mathrm{~h}$. After cooling to room temperature, the tube was opened and the reaction solution was neutralized with $1 \mathrm{~N} \mathrm{NaOH}$. The diluted solution was introduced onto an Amberlite IR-120 column and the adsorbed fraction was eluted with $1 \mathrm{~N} \mathrm{NH}_{4} \mathrm{OH}$. The eluate was evaporated under reduced pressure and the residue was recrystallized from $\mathrm{MeOH}$. The product $(10 \mathrm{mg})$ was identified as L-pipecolic acid on the basis of the following data. MS (FD): $m / z 130\left(\mathrm{M}^{+}+\mathrm{H}\right), 75.61 .[\alpha]_{\mathrm{D}}^{20}-32.7^{\circ}\left(\mathrm{H}_{2} \mathrm{O}, c=0.3\right) .{ }^{1} \mathrm{H}-\mathrm{NMR}$ $\left(\mathrm{D}_{2} \mathrm{O}\right)$ ppm: $1.54-1.96\left(5 \mathrm{H}, \mathrm{m}, \mathrm{C}_{3}-\mathrm{H}, \mathrm{C}_{4}, \mathrm{C}_{5}-2 \mathrm{H}\right), 2.18\left(1 \mathrm{H}, \mathrm{m}, \mathrm{C}_{3}-\mathrm{H}\right), 3.05\left(1 \mathrm{H}, \mathrm{m}, \mathrm{C}_{6}-\mathrm{H}\right), 3.36\left(1 \mathrm{H}, \mathrm{m}, \mathrm{C}_{6}-\mathrm{H}\right), 3.70$ $\left(1 \mathrm{H}, \mathrm{m}, \mathrm{C}_{2}-\mathrm{H}\right)$. These spectral data were identical with those of an authentic specimen.

Isolation of Ergosterol (IV), Its Peroxide (V) and Cerevisterol (VI)_-From the fraction (16.5 g) soluble in ethyl acetate, mentioned briefly in connection with the isolation of the new amino acid (I), a part (14.5 g) was chromatographed on $\mathrm{SiO}_{2}(70 \mathrm{~g})$. After elution with $n$-hexane, in which higher fatty acids and their esters were eluted, elution with $n$-hexane-AcOEt $(5: 1)$ provided ergosterol (III), as colorless needles after recrystallization from AcOEt. $R f$ on TLC 0.3 ( $n$-hexane: AcOEt $=5: 1) .{ }^{1} \mathrm{H}-\mathrm{NMR}\left(\mathrm{CDCl}_{3}\right) \mathrm{ppm}: 0.63(3 \mathrm{H}, \mathrm{s}), 0.84(6 \mathrm{H}, \mathrm{d}, J=8.0 \mathrm{~Hz}), 0.92(3 \mathrm{H}, \mathrm{d}$, $J=7.0 \mathrm{~Hz}), 0.94(3 \mathrm{H}, \mathrm{s}), 1.04(3 \mathrm{H}, \mathrm{d}, J=7.0 \mathrm{~Hz}), 3.60(1 \mathrm{H}, \mathrm{br} \mathrm{s}), 5.16-5.30(2 \mathrm{H}, \mathrm{m}), 5.41(1 \mathrm{H}, \mathrm{m}), 5.59(1 \mathrm{H}, \mathrm{dd}, J=$ $1.5 \mathrm{~Hz})$. The TLC behavior and ${ }^{1} \mathrm{H}-\mathrm{NMR}$ spectrum were compared with those of an authentic specimen of ergosterol (IV) and the two were confirmed to be identical. Elution with $n$-hexane-AcOEt $(4: 1)$ provided ergosterol peroxide (V) as colorless needles after recrystallization from AcOEt. $R f$ on TLC 0.2 ( $n$-hexane: AcOEt $=2: 1)$. ${ }^{1} \mathrm{H}-\mathrm{NMR}$ $\left(\mathrm{CDCl}_{3}\right)$ ppm: $0.77(3 \mathrm{H}, \mathrm{s}), 0.85(6 \mathrm{H}, \mathrm{d}, J=7.0 \mathrm{~Hz}), 0.88(6 \mathrm{H}, \mathrm{d}, J=7.0 \mathrm{~Hz}), 0.96(3 \mathrm{H}, \mathrm{s}), 1.10(3 \mathrm{H}, \mathrm{d}, J=6.0 \mathrm{~Hz})$, $5.18-5.35(2 \mathrm{H}, \mathrm{m}), 6.31(1 \mathrm{H}, \mathrm{d}, J=14.9 \mathrm{~Hz}), 6.60(1 \mathrm{H}, \mathrm{d}, J=14.0 \mathrm{~Hz})$. After comparison of the TLC behavior and ${ }^{1} \mathrm{H}-\mathrm{NMR}$ spectrum of the product with those of an authentic specimen, this isolated constituent was identified as ergosterol peroxide (V).

Elution with AcOEt, AcOEt-MeOH and $\mathrm{MeOH}$ provided gummy substances $(2.5 \mathrm{~g})$, which were chromatographed on $\mathrm{Al}_{2} \mathrm{O}_{3}(30 \mathrm{~g})$. After elution with a mixture of $n$-hexane and AcOEt, elution with AcOEt-MeOH (4:1) provided cerevisterol (VI) as colorless needles after recrystallization from AcOEt. mp $251-253{ }^{\circ} \mathrm{C} .{ }^{1} \mathrm{H}-\mathrm{NMR}$ (pyridine- $\left.d_{5}+\mathrm{CD}_{3} \mathrm{OD}\right)$ ppm: $0.65(3 \mathrm{H}, \mathrm{s}), 0.88(6 \mathrm{H}, \mathrm{d}, J=7.0 \mathrm{~Hz}), 0.90(3 \mathrm{H}, \mathrm{s}), 0.96(3 \mathrm{H}, \mathrm{d}, J=7.0 \mathrm{~Hz}), 1.01(3 \mathrm{H}, \mathrm{d}$, $J=6.0 \mathrm{~Hz}), 3: 61(1 \mathrm{H}, \mathrm{m}), 4.92(1 \mathrm{H}, \mathrm{br} \mathrm{d}, J=5 \mathrm{~Hz}), 5.20-5.36(2 \mathrm{H}, \mathrm{m}), 5.74(1 \mathrm{H}, \mathrm{br} \mathrm{d}, J=5.0 \mathrm{~Hz})$. After comparison of these data of an authentic specimen this compound was identified as cerevisterol (VI).

Amino Acids Analysis - Dried fruiting bodies (5.0 g) of $R$. subnigricans were extracted three times with water and the combined water solution was submitted to Amberlite IR-120 (50 ml) column chromatography. After washing of the column with distilled water, the amino acids fraction was eluted with $1 \mathrm{~N} \mathrm{NH}_{4} \mathrm{OH}$. The residue after evaporation under reduced pressure was analyzed in a JEOL amino analyzer (an analysis sample was prepared as a $1 \mathrm{mg} / \mathrm{ml}$ solution in $\mathrm{pH} 2.20 .2 \mathrm{~N}$ sodium citrate buffer). Column, JEOL AA pack Na; detection, fluorescence analysis with OPA treatment. The same fraction was also submitted to two-dimensional paper chromatography (solvent systems: 1) $\left.n-\mathrm{BuOH}: \mathrm{AcOH}: \mathrm{H}_{2} \mathrm{O}=4: 1: 1,2\right)$ phenol saturated with water). Dried fruiting bodies $(2.2 \mathrm{~g})$ of $R$. nigricans were extracted with water, followed by the usual treatment for preparation of the amino acids fraction. The obtained fraction was subjected to two-dimensional chromatography (Fig. 3). The fresh fruiting bodies (5.7 kg) of $R$. adusta were extracted with water, followed by the usual treatment for preparation of the amino acids fraction. The obtained fraction was subjected to two-dimensional paper chromatography (Fig. 3) and amino acids analysis (Thr, Glu, Pro, Glu, Ala, Cys, Val, Ileu, Leu, Tyr, Phe, $\gamma$-aminobutyric acid (GABA), Arg). Dried fruiting bodies (5.0 g) of 
L. piperatus were treated similarly, providing the two-dimensional paper chromatogram shown in Fig. 3 and amino acids (Asp, Thr, Ser, Glu, Pro, Gly, Ala, Val, Met, Ileu, Leu, Phe, Asp).

Acknowledgments The authors wish to thank Mr. H. Hayasaka and Mr. K. Ohba of this institute for collecting the mushrooms, Dr. Y. Koide of Kayaku Co., for amino acids analyses, Mr. K. Kawamura and Mrs. E. Niwa for the mass spectral analyses and Miss K. Mushiake for the NMR spectral analyses.

\section{References and Notes}

1) R. Imazeki and T. Hongo, "Colored Illustrations of Fungi of Japan," Vol. II, Hoikusha Publishing Co., Ltd., Osaka, 1976, p. 103.

2) O. Lutz and B. Jirgensons, Ber., 64, 1221 (1931).

3) F. E. King, T. J. King and A. J. Warwick, J. Chem. Soc., 45, 3590 (1950).

4) R. Watson and L. Fowden, Phytochemistry, 12, 617 (1973).

5) M. Marlier, G. Dardenne and J. Casimir, Phytochemistry, 15, 183 (1976).

6) G. Impellizzeri, S. Mangiafco, G. Oriente, M. Pianttelli, S. Sciuto, E. Fattorusso, S. Magno, C. Santacrose and D. Sica, Phytochemistry, 14, 1549 (1975).

7) A. van Harreveld, J. Neurobiol., 10, 355 (1979).

8) Melting points were measured on a Yanagimoto micro hot plate and are uncorrected. IR spectra were measured with a Shimadzu IR-27G infrared spectrometer. ${ }^{1} \mathrm{H}-\mathrm{NMR}$ spectra were taken with JEOL JNM-PMX60 (at $60 \mathrm{MHz}$ ) and JEOL JMN-FX-100 (100 MHz) spectrometers using tetramethylsilane as an internal (for organic solvents) or an external (for $\mathrm{D}_{2} \mathrm{O}$ solution) standard. ${ }^{13} \mathrm{C}$-NMR spectra were measured with a JEOL JMN-FX100 spectrometer operating at $25.05 \mathrm{MHz}$. The coupling patterns are indicated as follows: singlet $=\mathrm{s}$, doublet $=\mathrm{d}$, multiplet $=\mathrm{m}$, and broad $=$ br. Mass spectra were measured with Hitachi M-52 and JEOL JMS01SG-2 mass spectrometers. $[\alpha]_{\mathrm{D}}$ values were measured on a JACS DIP-340 polarimeter. 